\title{
Effects of Substrate Temperature on the Corrosion Behaviour of Nanochromium Coatings Deposited by Direct Current Magnetron Sputtering
}

\author{
Yanjie Ren, Jian Chen, Yaqing Chen, Jianlin Chen, and Wei Qiu \\ Department of Energy and Power Engineering, Changsha University of Science and Technology, Changsha 410076, China \\ Correspondence should be addressed to Yanjie Ren; yjren1008@163.com
}

Received 17 April 2016; Accepted 16 May 2016

Academic Editor: Lihui Liu

Copyright (c) 2016 Yanjie Ren et al. This is an open access article distributed under the Creative Commons Attribution License, which permits unrestricted use, distribution, and reproduction in any medium, provided the original work is properly cited.

Nanochromium coatings were deposited on 316L stainless steel bipolar plates of a proton-exchange membrane fuel cell (PEMFC) by a direct current magnetron sputtering technique. The effect of substrate temperature on the corrosion resistance of nanochromium coatings was investigated. The corrosion performance of the bare and chromium-coated steel in a simulated environment of PEMFC $\left(0.5 \mathrm{M} \mathrm{H}_{2} \mathrm{SO}_{4}+2 \mathrm{ppm} \mathrm{\textrm {F } ^ { - }}\right)$ was studied using electrochemical impedance spectroscopy, polarisation, and open circuit potential measurements. The results showed that the corrosion rates of two nanochromium coatings deposited at $300^{\circ} \mathrm{C}$ and $500^{\circ} \mathrm{C}$ were lower than those of uncoated steel by more than one order of magnitude. Electrochemical impedance spectra of both nanochromium coatings exhibited distinct characteristics in corrosive solution. The nanochromium coating deposited at $500^{\circ} \mathrm{C}$ showed superior stability in the corrosive solution.

\section{Introduction}

The proton-exchange membrane fuel cell (PEMFC) is a promising power generation system that converts energy, with water as the only by-product. The bipolar plate is a critical component of the PEMFC that conducts current between cells, facilitates water and thermal management through the cell, and distributes and separates the cathodic and anodic reactant gases. The main materials used for bipolar plates include graphite, metal, and graphite polymer composites. Graphite and graphite composites are the most commonly used bipolar plate materials due to their low surface contact resistance and high chemical stability. Unfortunately, graphite is too brittle to be machined to form thin plates with gas channels on each side, and it has relatively high gas permeability, which lowers the power density of the fuel cell stack. Metallic bipolar plates possess high electrical conductivity, acceptable material cost, high strength, and low gas permeability. Moreover, metallic materials could significantly reduce the volume and weight of a PEMFC [1]. The main problems associated with metallic materials are their inability to resist corrosion in a weakly acidic medium inside the PEMFC and the formation of passive films and metal ions. The formation of passive films increases the contact resistance, while the dissolution of metals contaminates the membrane electrodes [2]. To solve this problem, various protective coatings with high electrical conductivities have been proposed to protect the metallic bipolar plates to achieve high corrosion resistance and low contact resistance [3-9].

Chromium coating has frequently been used in the surface treatment of metals and alloys. It is accepted that both chromium itself and chromium coatings possess excellent corrosion resistance due to the formation of a passive film. It has been reported that nanocrystallisation of inactive metals and films could form a distinct passive film as a result of its different nucleation and growth process, which correlates with the corrosion behaviour and conductivity of coatings [10]. The characters of nanochromium coatings on the metallic bipolar plates have not yet been reported.

Chromium coatings are usually deposited on a substrate by either chemical or electrochemical methods. However, these approaches make use of toxic reactants and produce toxic waste products and pollutants. In addition, microcracks are formed during electrodeposition due to adsorbed 


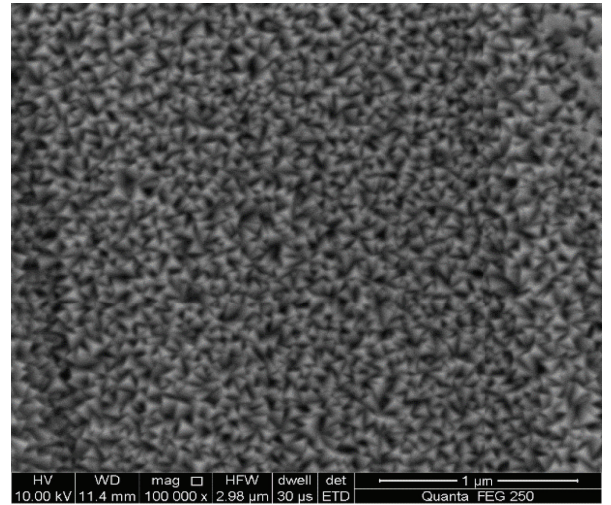

(a)

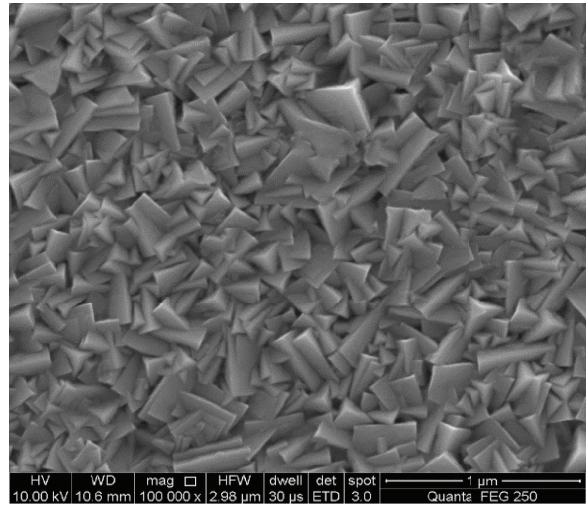

(b)

FIGURE 1: Surface morphology of nanochromium coatings deposited by magnetron sputtering with substrate temperatures (a) $300^{\circ} \mathrm{C}$ and $(\mathrm{b}$ ) $500^{\circ} \mathrm{C}$.

hydrogen atoms $[11,12]$. Magnetron sputtering is an effective technique for depositing coatings because it allows for easy control of the composition, crystal structure, and stoichiometry of each layer. It has therefore been widely used for the deposition of corrosion-resistant, wear-resistant, and electrically insulating coatings and for decorative coatings on workpieces $[13,14]$.

In this study, we focused on the effect of substrate temperature on the corrosion behaviour of nanoscale chromium coatings on 316L stainless steel bipolar plates of a PEMFC. The deposited films were characterized by scanning electron microscopy (SEM) and X-ray diffraction (XRD). The corrosion resistance of the chromium films was investigated by potentiodynamic polarisation measurements and electrochemical impedance spectroscopy (EIS).

\section{Experimental Methods}

2.1. Preparation of Nanochromium Coatings. $316 \mathrm{~L}$ stainless steel was used as the substrate alloy. The steel plates were cut into specimens of $20 \times 20 \mathrm{~mm}$, followed by grinding with 1000-grit silicon carbide $(\mathrm{SiC})$ paper and degreasing with acetone $\left(\left(\mathrm{CH}_{3}\right)_{2} \mathrm{CO}\right)$. A multitarget reactive DC magnetron sputtering system (JZCK-450, Intelligence-Gathering Vacuum Equipment Co., Ltd., China) was employed and a base vacuum pressure of $8.0 \times 10^{-3} \mathrm{~Pa}$ was used. Chromium target coverage of $99.99 \%$ at room temperature (RT) was used and an interelectrode distance was $10 \mathrm{~cm}$. The ion current density was $0.35 \mathrm{~A}$. The substrate temperatures were $300^{\circ} \mathrm{C}$ and $500^{\circ} \mathrm{C}$. The sputtering time was $2 \mathrm{~h}$. Scanning electron microscopy (SEM) and X-ray diffraction (XRD) were employed to characterize the coatings. Jade 5.0 software was used to evaluate the grain size of the chromium films.

2.2. Electrochemical Measurements. A conventional threeelectrode system was used for the electrochemical measurements, with a platinum sheet as the counter electrode and a saturated calomel electrode (SCE) as the reference electrode. All electrochemical measurements were carried out in $0.5 \mathrm{M} \mathrm{H}_{2} \mathrm{SO}_{4}+2 \mathrm{ppm} \mathrm{F}^{-}$solution at RT with a
Zahner Zennium Potentiostat/Galvanostat. Potentiodynamic polarisation measurements used a scan rate of $20 \mathrm{mV} \mathrm{min}^{-1}$ following immersion for $1 \mathrm{~h}$ in $0.5 \mathrm{M} \mathrm{H}_{2} \mathrm{SO}_{4}+2 \mathrm{ppm} \mathrm{F}^{-}$solution. Electrochemical impedance measurements were carried out in the range $0.01-100 \mathrm{kHz}$ at open circuit potential (OCP). The amplitude of the input sine wave voltage was $5 \mathrm{mV}$.

\section{Results and Discussion}

3.1. Morphology and Microstructure. Figure 1 shows the surface morphology of chromium coatings deposited at $300^{\circ} \mathrm{C}$ (named $\mathrm{Cr}-1$ ) and $500^{\circ} \mathrm{C}$ (named $\mathrm{Cr}-2$ ), but otherwise with identical deposition parameters, as mentioned in Section 2. The specimens having the $\mathrm{Cr}-1$ coating exhibited a threedimensional island structure with an open boundary (Figure 1(a)), with an average grain size of about $50 \mathrm{~nm}$. It was observed that obvious defects existed within it. In contrast, the Cr-2 coating exhibited a compact pyramidal structure with a variable grain size that was larger than that of the Cr1 specimens (as shown in Figure 1(b)). The nucleation and growth of as-deposited films are thermodynamic nonequilibrium processes. As the substrate temperature is low, the critical nucleation free energy is low, which results in a smaller grain dimension of as-deposited coating. When the substrate temperature increases, the grain dimension also increases due to the higher critical nucleation free energy [15]. In contrast, at low substrate temperatures the atoms diffuse with difficulty and produce shadow effects, which contribute to the columnar structure of the coatings [16]. However, at high substrate temperatures the sputtered atoms diffuse easily and the self-shadow effect is avoided. It was observed that the Cr-2 coating showed a more compact structure.

The XRD patterns of chromium films deposited at $300^{\circ} \mathrm{C}$ and $500^{\circ} \mathrm{C}$ are shown in Figure 2. $\mathrm{Cr}$ (110) and $\mathrm{Cr}$ (211) peaks can be seen clearly. An additional Cr (200) peak appeared for Cr-2 coating.

3.2. Electrochemical Polarisation Measurements. Figure 3 shows the potentiodynamic polarisation curves for bare steel and for chromium coatings in $0.5 \mathrm{M} \mathrm{H}_{2} \mathrm{SO}_{4}+2 \mathrm{ppm} \mathrm{F}^{-}$ 


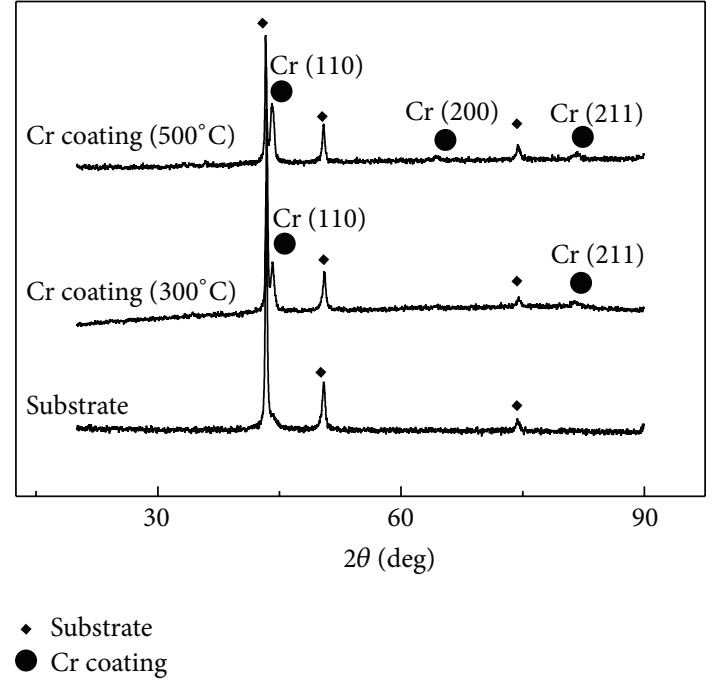

FIGURE 2: XRD patterns of chromium films with substrate temperatures $300^{\circ} \mathrm{C}$ and $500^{\circ} \mathrm{C}$ by magnetron sputtering.

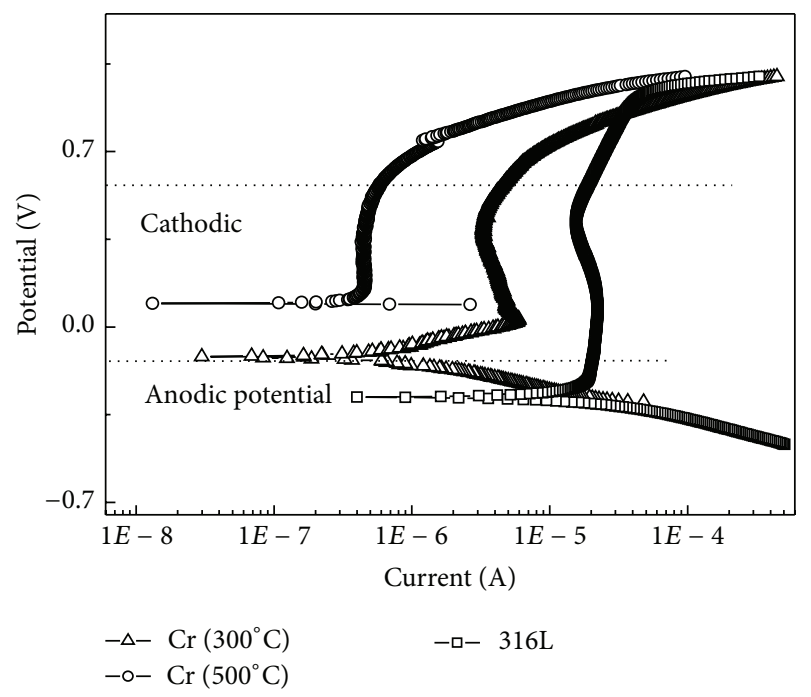

FIgUre 3: Potentiodynamic polarisation curves for 316L stainless steel and nanochromium coatings in $0.5 \mathrm{M} \mathrm{H}_{2} \mathrm{SO}_{4}+2 \mathrm{ppm} \mathrm{F}^{-}$ solution.

solution at room temperature, respectively. Both the Cr-2 coating and the $316 \mathrm{~L}$ stainless steel were in a passive state at the corrosion potential $\left(E_{\text {corr }}\right)$. The chromium coatings deposited at $300^{\circ} \mathrm{C}$ were in an active state at $E_{\text {corr }}$ at $-119 \mathrm{mV}$ SCE. The increased current density of the Cr-1 coating is related to its smaller grain size and open structure, which enlarged the exposed area to the corrosive solution. $E_{\text {corr }}$ and the corrosion current density $\left(I_{\text {corr }}\right)$ for $316 \mathrm{~L}$ stainless steel were $-289 \mathrm{mV} \mathrm{SCE}$ and $20.1 \mu \mathrm{A} \mathrm{cm}^{-2}$, respectively. $E_{\text {corr }}$ and $I_{\text {corr }}$ for the Cr-1 coating were $-119 \mathrm{mV} \mathrm{SCE}$ and $1.27 \mu \mathrm{A} \mathrm{cm}{ }^{-2}$, while for the $\mathrm{Cr}-2$ coating with a compact structure they were $96 \mathrm{mV} \mathrm{SCE}$ and $0.35 \mu \mathrm{A} \mathrm{cm}^{-2}$, respectively.

The cathode operation potential at $0.6 \mathrm{~V} \mathrm{SCE}$ was marked by the dotted line and the passivation current density of
316L stainless steel at the cathode operation potential was $19.5 \mu \mathrm{A} \mathrm{cm}^{-2}$. In contrast, the current densities of the Cr1 and $\mathrm{Cr}-2$ coatings were significantly reduced to 4.83 and $0.59 \mu \mathrm{A} \mathrm{cm}^{-2}$, respectively. The smaller anodic current density usually implied better durability and a lower corrosion rate. The anode potential $(-0.1 \mathrm{~V} \mathrm{SCE})$ was in the active region of 316L stainless steel and the Cr-1 coating, and the current densities were $19.8 \mu \mathrm{A} \mathrm{cm}^{-2}$ and $0.41 \mu \mathrm{Acm}^{-2}$, respectively, but the corrosion potential of the Cr- 2 coating shifted towards the positive direction, reaching about $96 \mathrm{mV}$ SCE. This was more positive than the operating potential in the PEMFC anode environment. Hence, the anode operation potential was cathodic to $\mathrm{Cr}-2$ and corrosion was retarded.

3.3. Open Circuit Potential Measurements. The high stability of nanochromium coatings in $0.5 \mathrm{M} \mathrm{H}_{2} \mathrm{SO}_{4}+2 \mathrm{ppm} \mathrm{F}^{-}$ solution was also demonstrated by the measurements of open circuit potential versus time curves for chromium-coated and the bare steel, as shown in Figures 4(a) and 4(b), respectively. For $316 \mathrm{~L}, E_{\text {ocp }}$ was maintained at about $-250 \mathrm{mV}$ SCE in corrosive solution (Figure 4(a)). As shown in Figure 4(b), $E_{\text {ocp }}$ for $\mathrm{Cr}-1$ coatings increased to $278 \mathrm{mV}$ SCE during immersion for $264 \mathrm{~h}$ in corrosive solution and then decreased gradually. For the $\mathrm{Cr}-2$ coating, $E_{\text {ocp }}$ increased after immersion for $768 \mathrm{~h}$ and its potential remained at about $400 \mathrm{mV} \mathrm{SCE}$. As a passive layer developed, the OCP of $\mathrm{Cr}-2$ coatings increased and remained stable. The OCP was higher than that reported in the literature [12], which was related to nanostructures of the coating. The corrosion resistance of the chromium coating deposited at $300^{\circ} \mathrm{C}$ shows inferior stability due to its open structure, compared with that deposited at $500^{\circ} \mathrm{C}$.

3.4. Electrochemical Impedance Measurements. Figure 5 showed the typical Nyquist and Bode plots for the corrosion of $316 \mathrm{~L}$ stainless steel in $0.5 \mathrm{M} \mathrm{H}_{2} \mathrm{SO}_{4}+2 \mathrm{ppm} \mathrm{F}^{-}$solution after various exposure times. The Nyquist plots were composed of two depressed semicircles. An equivalent circuit of Figure 6 was proposed to fit the impedance plots. $R_{\mathrm{s}}$ was the electrolyte resistance. $R_{\mathrm{f}}$ and $C_{\mathrm{f}}$ represented, respectively, the resistance and capacitance of the porous corrosion products formed on the alloy surface. $R_{\mathrm{t}}$ and $C_{\mathrm{dl}}$ were the charge transfer resistance and double-layer capacitance, respectively. A constant phase element (CPE) was used in the fitting procedures. Table 1 gives the fitted results of impedance spectra for the corrosion of 316L stainless steel. It could be observed that the values of $R_{\mathrm{t}}$ tend to increase with exposure time, suggesting a decreased corrosion rate.

Differing from the bare steel, the impedance spectra of Cr-1 coating exhibit different characters in the corrosive solution. After immersion for $1 \mathrm{~h}$, the Nyquist plots consist of two capacitive loops, as shown in Figure 7(a), which were correlated with an incomplete chromium oxide film. With extended immersion time, the Nyquist plots consist of a small capacitive loop in the high-frequency region and a nearly vertical line at low frequency, as shown in Figure 7(b). The Bode diagrams show a large frequency region of the maximum phase angle, with values greater than $85^{\circ}$, close to the $90^{\circ}$ value, which are characteristic of a predominantly 


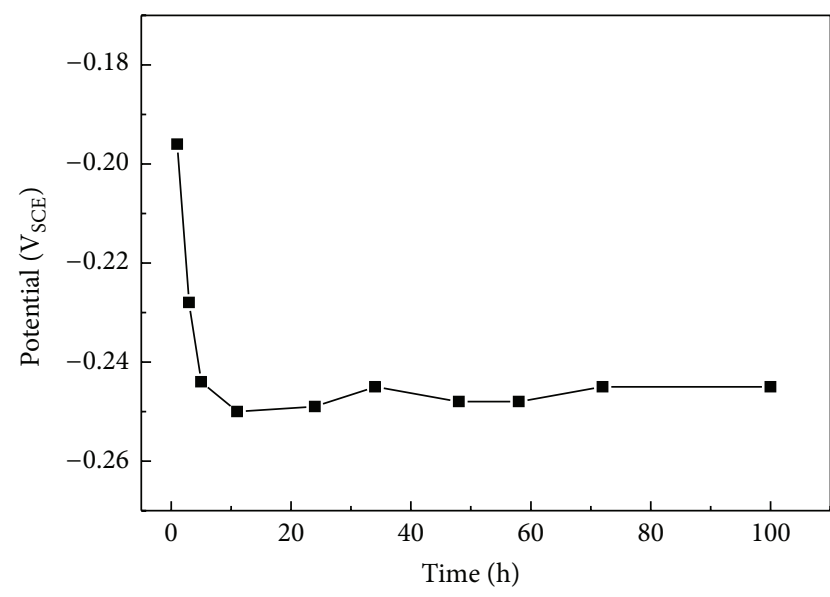

(a)

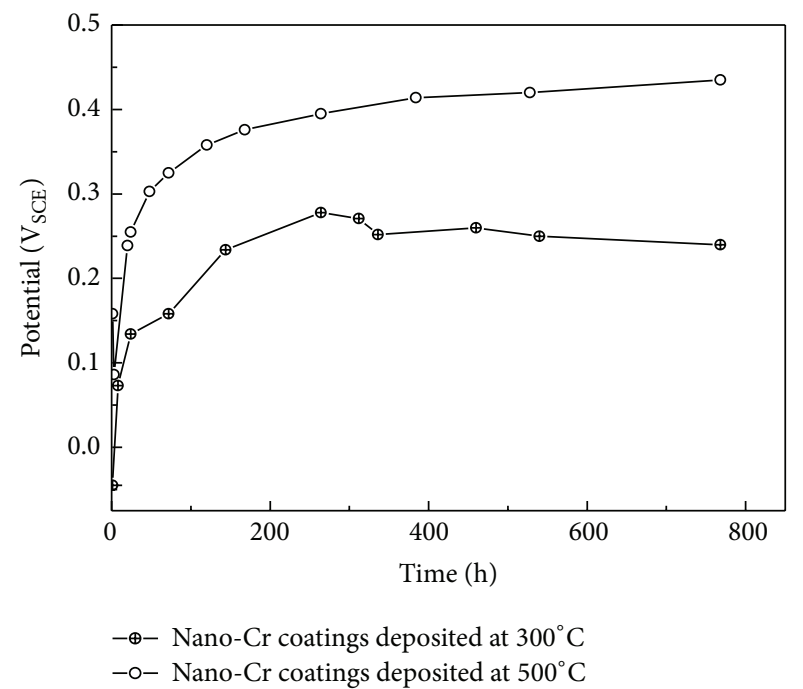

(b)

FIgURE 4: Open circuit potential-time curves for (a) 316L and (b) nano-Cr-1 and nano-Cr-2 coatings in $0.5 \mathrm{M} \mathrm{H}_{2} \mathrm{SO}_{4}+2 \mathrm{ppm} \mathrm{F}^{-}$solution.
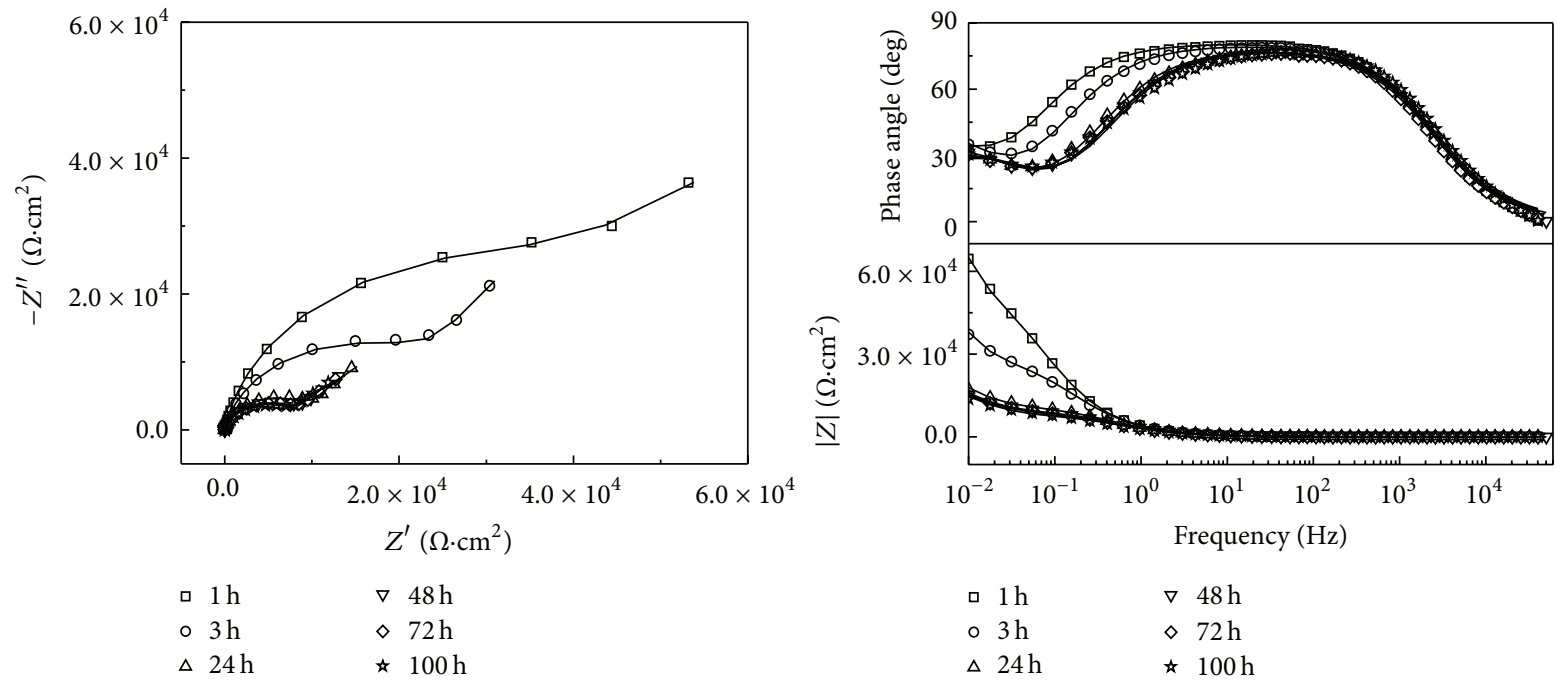

FIGURE 5: Nyquist and Bode plots for $316 \mathrm{~L}$ after various exposure times at open circuit potential in $0.5 \mathrm{M} \mathrm{H}_{2} \mathrm{SO}_{4}+2 \mathrm{ppm} \mathrm{F}^{-}$solution. Symbols: experimental data; line: fitted data.

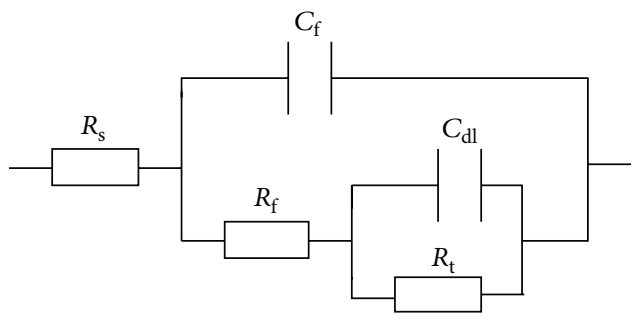

FIGURE 6: Equivalent circuit representing the corrosion of $316 \mathrm{~L}$ in $0.5 \mathrm{M} \mathrm{H}_{2} \mathrm{SO}_{4}+2 \mathrm{ppm} \mathrm{F}^{-}$solution.

capacitive behaviour. For some anodised valve metals (such as $\mathrm{Ti}, \mathrm{Bi}$, and $\mathrm{Al}$ ), EIS show similar characteristics in the initial period of oxide film formation in aqueous solution $[17,18]$. However, previous studies have not reported similar results for chromium or other inactive films containing a developed passive film. Since the passive film formation is mainly determined by nucleation and growth processes, defects, dislocations, grain boundaries, and grain boundary junctions generate nucleation of passive films [19]. Compared to coarse-grained structures, nanocrystalline materials are composed of a large fraction of surface defects which alter the nucleation mechanism of passive films from progressive to instantaneous. Passive films are composed of multilayers, investigated by a potentiostatic-galvanostatic (P-G) transient technique, which are different from those grown on coarsegrained materials [20]. 


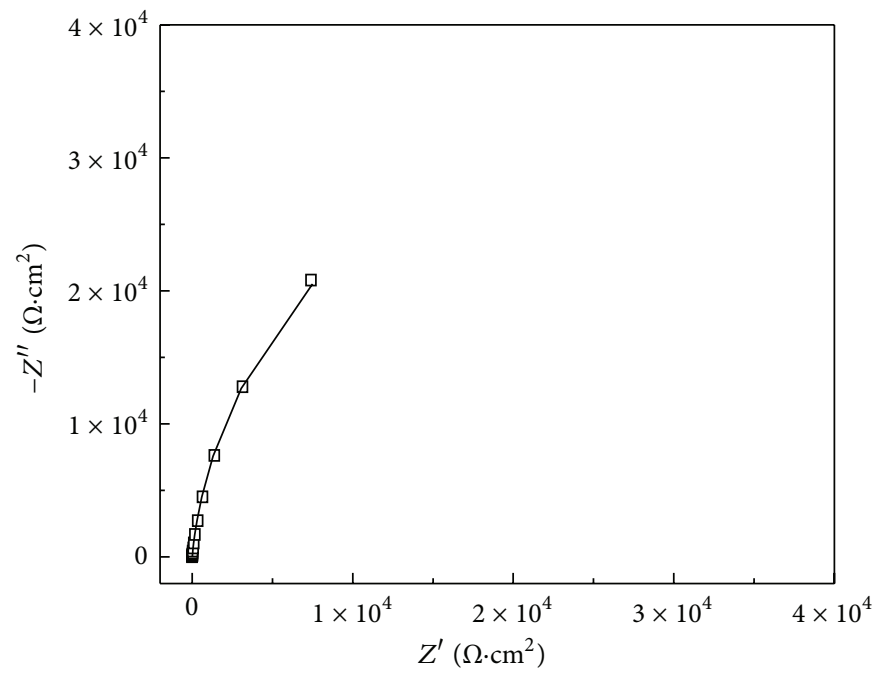

口 $1 \mathrm{~h}$

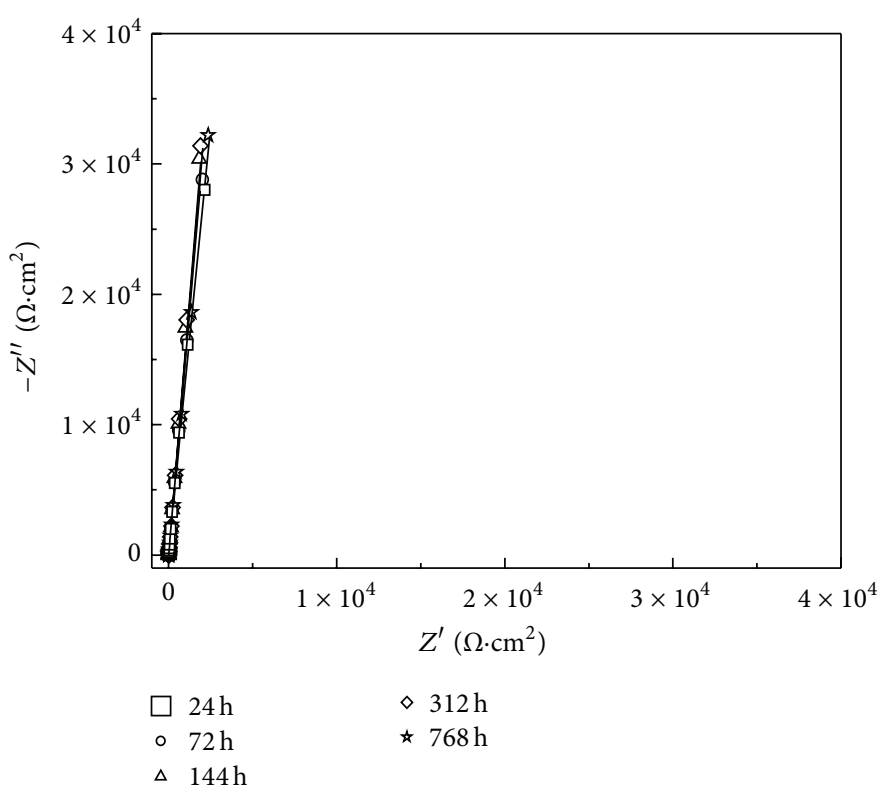

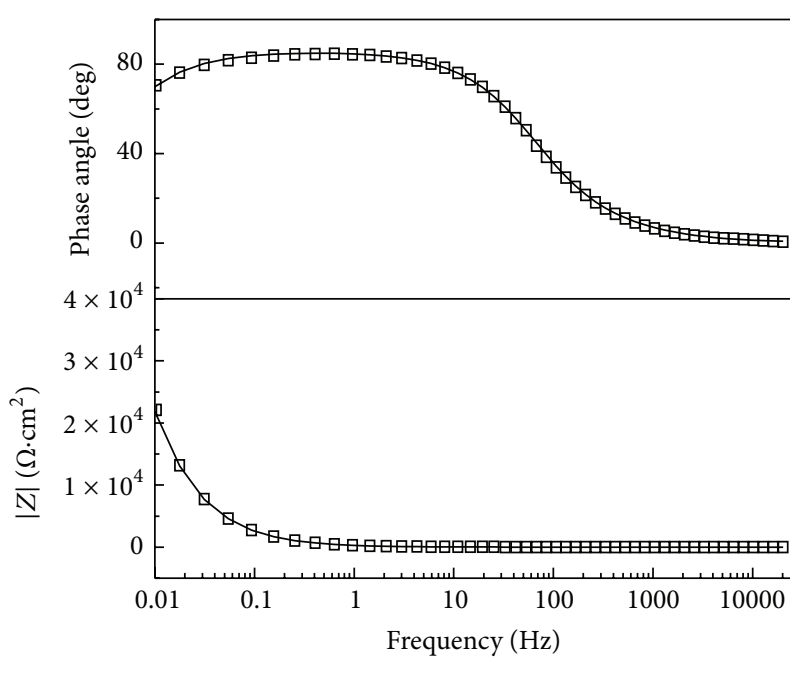

a $1 \mathrm{~h}$

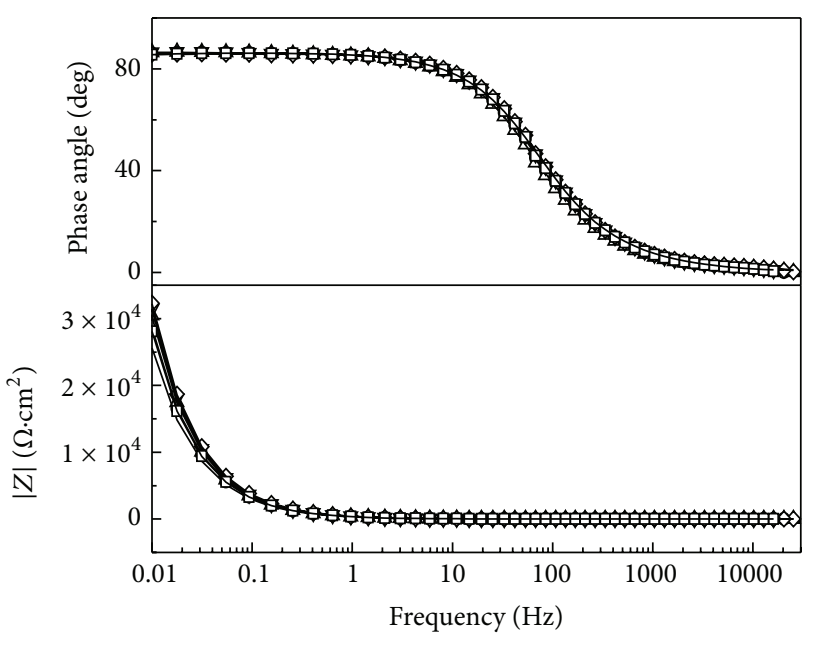

(b)

Figure 7: Nyquist and Bode plots for nanochromium coatings with substrate temperature $300^{\circ} \mathrm{C}$ after various exposure times at open circuit potential in $0.5 \mathrm{M} \mathrm{H}_{2} \mathrm{SO}_{4}+2 \mathrm{ppm} \mathrm{F}^{-}$solution. Symbols: experimental data; line: fitted data.

TABLE 1: Fitting results of impedance spectra for the corrosion of $316 \mathrm{~L}$ stainless steel in $0.5 \mathrm{M} \mathrm{H}_{2} \mathrm{SO}_{4}+2 \mathrm{ppm} \mathrm{F}^{-}$solution.

\begin{tabular}{lccccccc}
\hline Time $(\mathrm{h})$ & $R_{\mathrm{s}}\left(\Omega \cdot \mathrm{cm}^{2}\right)$ & $Y_{\mathrm{f}}\left(\Omega^{-1} \cdot \mathrm{cm}^{-2} \mathrm{~S}^{-n}\right)$ & $n_{\mathrm{f}}$ & $R_{\mathrm{f}}\left(\Omega \cdot \mathrm{cm}^{2}\right)$ & $Y_{\mathrm{dl}}\left(\Omega \cdot \mathrm{cm}^{2} \mathrm{~S}^{-n}\right)$ & $n_{\mathrm{dl}}$ & $R_{\mathrm{t}}\left(\Omega \cdot \mathrm{cm}^{2}\right)$ \\
\hline 1 & 2.041 & $8.164 E-5$ & 0.850 & 0.033 & $1.583 E-5$ & 0.992 & $1.490 E 4$ \\
3 & 1.835 & $8.427 E-5$ & 0.838 & 0.039 & $1.548 E-5$ & 0.865 & $9.420 E 3$ \\
24 & 1.982 & $2.758 E-5$ & 0.978 & 5.070 & $9.695 E-5$ & 0.748 \\
100 & 1.683 & $3.126 E-5$ & 0.912 & 6.084 & $1.080 E-4$ & 0.733 & $4.441 E 3$ \\
\hline
\end{tabular}



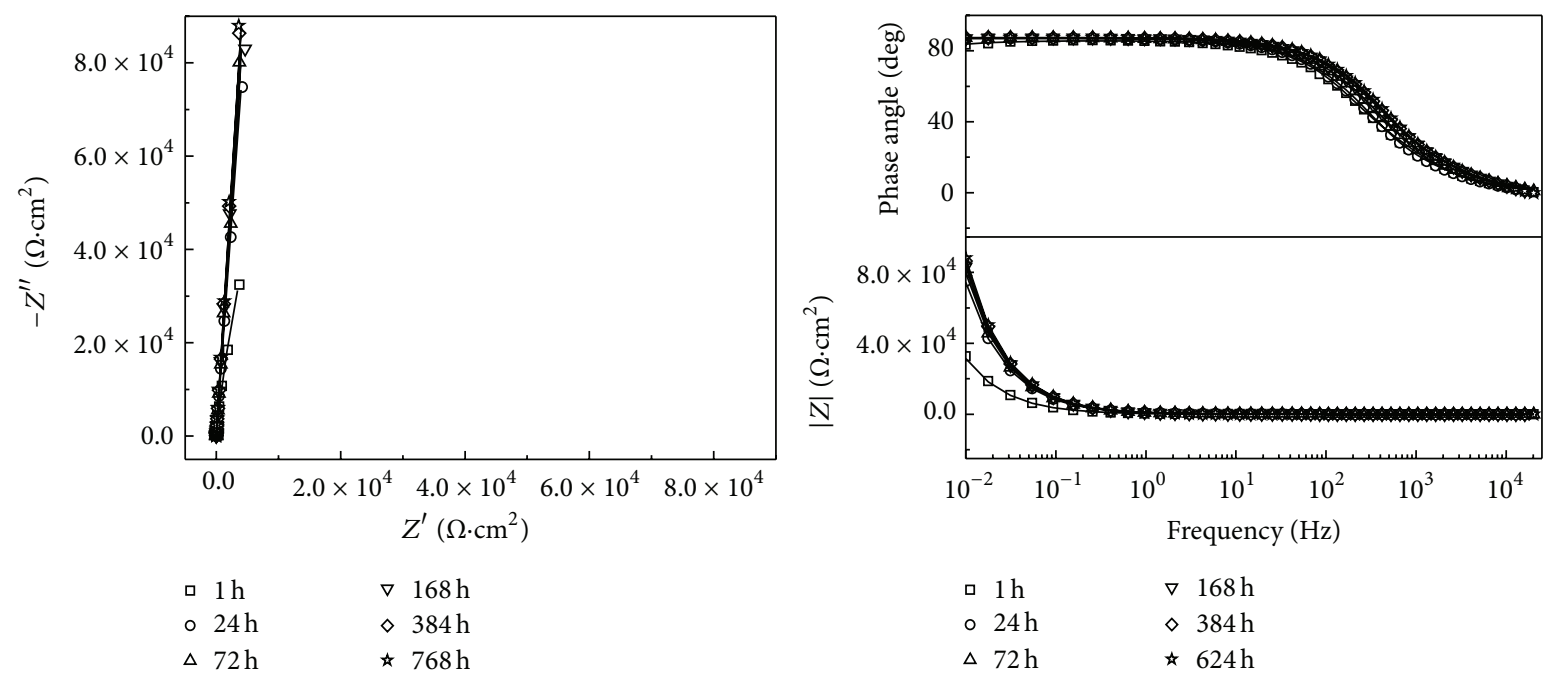

FIGURE 8: Nyquist and Bode plots for nanochromium coatings with substrate temperature $500^{\circ} \mathrm{C}$ after various exposure times at open circuit potential in $0.5 \mathrm{M} \mathrm{H}_{2} \mathrm{SO}_{4}+2 \mathrm{ppm} \mathrm{F}^{-}$solution. Symbols: experimental data; line: fitted data.

TABLE 2: Fitting results of impedance spectra for the corrosion of Cr-1 coatings in $0.5 \mathrm{M} \mathrm{H}_{2} \mathrm{SO}_{4}+2 \mathrm{ppm} \mathrm{F}^{-}$solution.

\begin{tabular}{lccccccc}
\hline Time $(\mathrm{h})$ & $R_{\mathrm{s}}\left(\Omega \cdot \mathrm{cm}^{2}\right)$ & $Y_{\mathrm{f}}\left(\Omega^{-1} \cdot \mathrm{cm}^{-2} \mathrm{~S}^{-n}\right)$ & $n_{\mathrm{f}}$ & $R_{\mathrm{f}}\left(\Omega \cdot \mathrm{cm}^{2}\right)$ & $Y_{\mathrm{dl}}\left(\Omega \cdot \mathrm{cm}^{2} \mathrm{~S}^{-n}\right)$ & $n_{\mathrm{dl}}$ & $R_{\mathrm{t}}\left(\Omega \cdot \mathrm{cm}^{2}\right)$ \\
\hline 1 & 2.191 & $6.605 E-4$ & 0.958 & 1.348 & $5.488 E-4$ & 0.944 & $4.063 E 4$ \\
24 & 2.274 & $4.905 E-4$ & 0.969 & 1.141 & $5.229 E-4$ & 0.946 & - \\
72 & 2.385 & $4.612 E-4$ & 0.967 & 1.030 & $5.346 E-4$ & 0.950 & - \\
144 & 2.728 & $3.997 E-4$ & 0.965 & 0.937 & $5.435 E-4$ & 0.953 & - \\
312 & 2.499 & $3.891 E-4$ & 0.967 & 0.986 & $5.18 E-4$ & 0.951 & - \\
768 & 2.546 & $2.557 E-4$ & 0.963 & 0.671 & $6.158 E-4$ & 0.945 & - \\
\hline
\end{tabular}

TABLE 3: Fitting results of impedance spectra for the corrosion of Cr-2 coatings in $0.5 \mathrm{M} \mathrm{H}_{2} \mathrm{SO}_{4}+2 \mathrm{ppm} \mathrm{F}^{-}$solution.

\begin{tabular}{lccccc}
\hline Time $(\mathrm{h})$ & $R_{\mathrm{s}}\left(\Omega \cdot \mathrm{cm}^{2}\right)$ & $Y_{\mathrm{f}}\left(\Omega^{-1} \cdot \mathrm{cm}^{-2} \mathrm{~S}^{n}\right)$ & $n_{\mathrm{f}}$ & $R_{\mathrm{f}}\left(\Omega \cdot \mathrm{cm}^{2}\right)$ & $Y_{\mathrm{d}}\left(\Omega^{-1} \cdot \mathrm{cm}^{-2} \mathrm{~S}^{-n}\right)$ \\
\hline 1 & 1.501 & $2.796 E-4$ & 0.962 & 2.606 & $1.647 E-4$ \\
72 & 1.307 & $2.291 E-4$ & 0.974 & 2.414 & $1.378 E-4$ \\
168 & 1.174 & $2.220 E-4$ & 0.979 & 2.903 & $1.309 E-4$ \\
384 & 1.174 & $2.212 E-4$ & 0.978 & 2.490 & $1.209 E-4$ \\
768 & 1.162 & $2.266 E-4$ & 0.976 & 2.662 & 0.952 \\
\hline
\end{tabular}

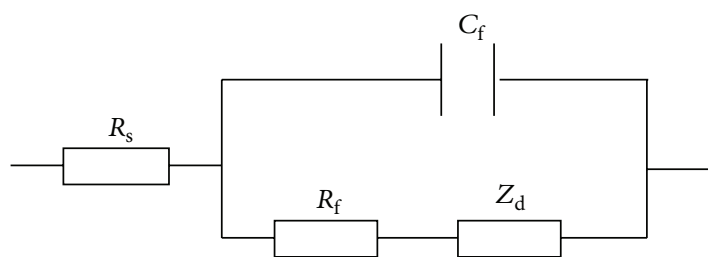

FIGURE 9: Equivalent circuit representing the corrosion of nanochromium coatings in $0.5 \mathrm{M} \mathrm{H}_{2} \mathrm{SO}_{4}+2 \mathrm{ppm} \mathrm{F}^{-}$solution.

For the Cr- 2 coating, the EIS consist of a small capacitive loop in the high-frequency region and a nearly vertical line at low frequency during the initial stage and maintain the same character for the total period of immersion. The impedance diagrams for initial immersion $(1 \mathrm{~h})$ of coatings at $300^{\circ} \mathrm{C}$ can be fitted by the equivalent circuit shown in Figure 6. The subsequent diagrams and those of the coatings formed at $500^{\circ} \mathrm{C}$ can be represented by the equivalent circuit shown in Figure 9, where $C_{\mathrm{f}}$ represents the film capacitance, $R_{\mathrm{f}}$ is the resistance of the chromium film, and $Z_{\mathrm{d}}$ is the diffusion impedance of migrating chromium ions along the passive film. Figures 7 and 8 show that there is a close fit for the EIS spectra of nanochromium-coated steel in $0.5 \mathrm{M} \mathrm{H}_{2} \mathrm{SO}_{4}$ +2 ppm F $\mathrm{F}^{-}$solution. Some electrochemical parameters are given in Tables 2 and 3 .

The values of $R_{\mathrm{f}}$ for the Cr-1 coating decreased from $1.348 \Omega \cdot \mathrm{cm}^{2}$ to $0.671 \Omega \cdot \mathrm{cm}^{2}$ up to $768 \mathrm{~h}$. However, the values of $R_{\mathrm{f}}$ of the Cr-2 coating remained stable with some fluctuation, indicating that the $\mathrm{Cr}-2$ coating retained high chemical stability in solution. The values of $n_{\mathrm{f}}$ related to surface roughness and the distribution of corrosion current on the electrode were close to 1 and almost remained constant, suggesting that a stable, passive film was formed for Cr-2 coatings. 


\section{Conclusions}

The effects of substrate temperature on the corrosion behaviour of nanochromium coatings on 316L stainless steel bipolar plates of a proton-exchange membrane fuel cell were evaluated. The chromium film deposited at $300^{\circ} \mathrm{C}$ presented a three-dimensional island structure, with an average grain size about $50 \mathrm{~nm}$ and containing obvious pores. However, the microstructure of the chromium film deposited at $500^{\circ} \mathrm{C}$ was dense, with an increasing grain size. In $0.5 \mathrm{M} \mathrm{H}_{2} \mathrm{SO}_{4}+$ $2 \mathrm{ppm} \mathrm{F}^{-}$solution, the nanochromium coatings deposited at $300^{\circ} \mathrm{C}$ and $500^{\circ} \mathrm{C}$ significantly increased the free corrosion potential of the steel, and its corrosion current density was one or two orders of magnitude lower than that of the bare steel. The nanochromium coatings offer excellent corrosion protection for 316L stainless steel in simulated PEMFC environments. In contrast, the chromium coatings deposited with substrate temperature $500^{\circ} \mathrm{C}$ exhibited superior stability to that obtained with substrate temperature $300^{\circ} \mathrm{C}$.

The ongoing research work includes the contact electric resistance and the corrosion resistance of nanochromium coatings in actual PEMFC conditions.

\section{Competing Interests}

The authors declare that they have no competing interests.

\section{Acknowledgments}

This project was supported by the National Natural Science Foundation of China (Grant no. 51301026), Natural Science Foundation of Hunan Province (Grant no. 14JJ6019), and the Educational Commission of Hunan Province (Grant no. 13B128).

\section{References}

[1] H. Tsuchiya and O. Kobayashi, "Mass production cost of PEM fuel cell by learning curve," International Journal of Hydrogen Energy, vol. 29, no. 10, pp. 985-990, 2004.

[2] A. E. Fetohi, R. M. Abdel Hameed, K. M. El-Khatib, and E. R. Souaya, "Study of different aluminum alloy substrates coated with Ni-Co-P as metallic bipolar plates for PEM fuel cell applications," International Journal of Hydrogen Energy, vol. 37, no. 14, pp. 10807-10817, 2012.

[3] H. L. Wang and J. A. Turner, "Electrochemical nitridation of a stainless steel for PEMFC bipolar plates," International Journal of Hydrogen Energy, vol. 36, no. 20, pp. 13008-13013, 2011.

[4] E. M. Gabreab, G. Hinds, S. Fearn et al., "An electrochemical treatment to improve corrosion and contact resistance of stainless steel bipolar plates used in polymer electrolyte fuel cells," Journal of Power Sources, vol. 245, pp. 1014-1026, 2014.

[5] M. C. Li, S. Z. Luo, C. Zeng, J. Shen, H. Lin, and C. Cao, "Corrosion behavior of TiN coated type 316 stainless steel in simulated PEMFC environments," Corrosion Science, vol. 46, no. 6, pp. 1369-1380, 2004.

[6] D. W. DeBerry, "Modification of the electrochemical and corrosion behavior of stainless steels with an electroactive coating," Journal of the Electrochemical Society, vol. 132, no. 5, pp. 10221026, 1985.
[7] D. O. Flamini and S. B. Saidman, "Electrodeposition of polypyrrole onto NiTi and the corrosion behaviour of the coated alloy," Corrosion Science, vol. 52, no. 1, pp. 229-234, 2010.

[8] L. M. Martins dos Santos, J. C. Lacroix, K. I. Chane-Ching, A. Adenier, L. M. Abrantes, and P. C. Lacaze, "Electrochemical synthesis of polypyrrole films on copper electrodes in acidic and neutral aqueous media," Journal of Electroanalytical Chemistry, vol. 587, no. 1, pp. 67-78, 2006.

[9] K. Qi, Y. B. Qiu, Z. Y. Chen, and X. P. Guo, "Corrosion of conductive polypyrrole: Galvanic interactions between polypyrrole and metal substrates," Corrosion Science, vol. 91, pp. 272-280, 2015.

[10] G. Ćirić-Marjanović, "Recent advances in polyaniline research: polymerization mechanisms, structural aspects, properties and applications," Synthetic Metals, vol. 177, pp. 1-47, 2013.

[11] A. Lozano-Morales, R. P. Renz, J. J. Fortman, and E. J. Taylor, "Electrically mediated process for functional and decorative trivalent chromium electroplating: an alternative to hexavalent chromium," ECS Transactions, vol. 6, pp. 51-61, 2007.

[12] Z. X. Zeng and J. Y. Zhang, "Electrodeposition and tribological behavior of amorphous chromium-alumina composite coatings," Surface and Coatings Technology, vol. 202, no. 12, pp. 27252730, 2008.

[13] D. Rosestolato, G. Battaglin, and S. Ferro, "Electrochemical properties of stoichiometric RuN film prepared by rfmagnetron sputtering: a preliminary study," Electrochemistry Communications, vol. 49, pp. 9-13, 2014.

[14] K. Nygren, M. Samuelsson, A. Flink, H. Ljungcrantz, Å. K. Rudolphi, and U. Jansson, "Growth and characterization of chromium carbide films deposited by high rate reactive magnetron sputtering for electrical contact applications," Surface and Coatings Technology, vol. 260, pp. 326-334, 2014.

[15] D. B. Lewis, Q. Luo, P. E. Hovsepian, and W.-D. Münz, "Interrelationship between atomic species, bias voltage, texture and microstructure of nano-scale multilayers," Surface and Coatings Technology, vol. 184, no. 2-3, pp. 225-232, 2004.

[16] D. Lan, Y. Wang, and Z. Q. Cao, "Studies on the corrosion elecrochemical behavior of nanocrystalline $\mathrm{Cr}$ in acidic media," Journal of Liaoning Technology University, vol. 31, pp. 387-391, 2012.

[17] A.-C. Manea, M. Buda, and T. Vişan, "Electrochemical impedance spectroscopy investigations of tantalum and its passive films in some acidic solutions," UPB Scientific Bulletin, Series B: Chemistry and Materials Science, vol. 72, no. 4, pp. 6578, 2010.

[18] T. D. Radjabov, A. I. Kamardin, and A. V. Sharudo, "The investigation of two-layer protective-decorative coatings on oxide substrates," Vacuum, vol. 75, no. 2, pp. 143-147, 2004.

[19] T. S. Li, L. Liu, B. Zhang et al., "Passive behavior of a bulk nanostructured 316L austenitic stainless steel consisting of nanometer-sized grains with embedded nano-twin bundles," Corrosion Science, vol. 85, pp. 331-342, 2014.

[20] C. Pan, L. Liu, Y. Li, S. Wang, and F. Wang, "Passive film growth mechanism of nanocrystalline 304 stainless steel prepared by magnetron sputtering and deep rolling techniques," Electrochimica Acta, vol. 56, no. 22, pp. 7740-7748, 2011. 

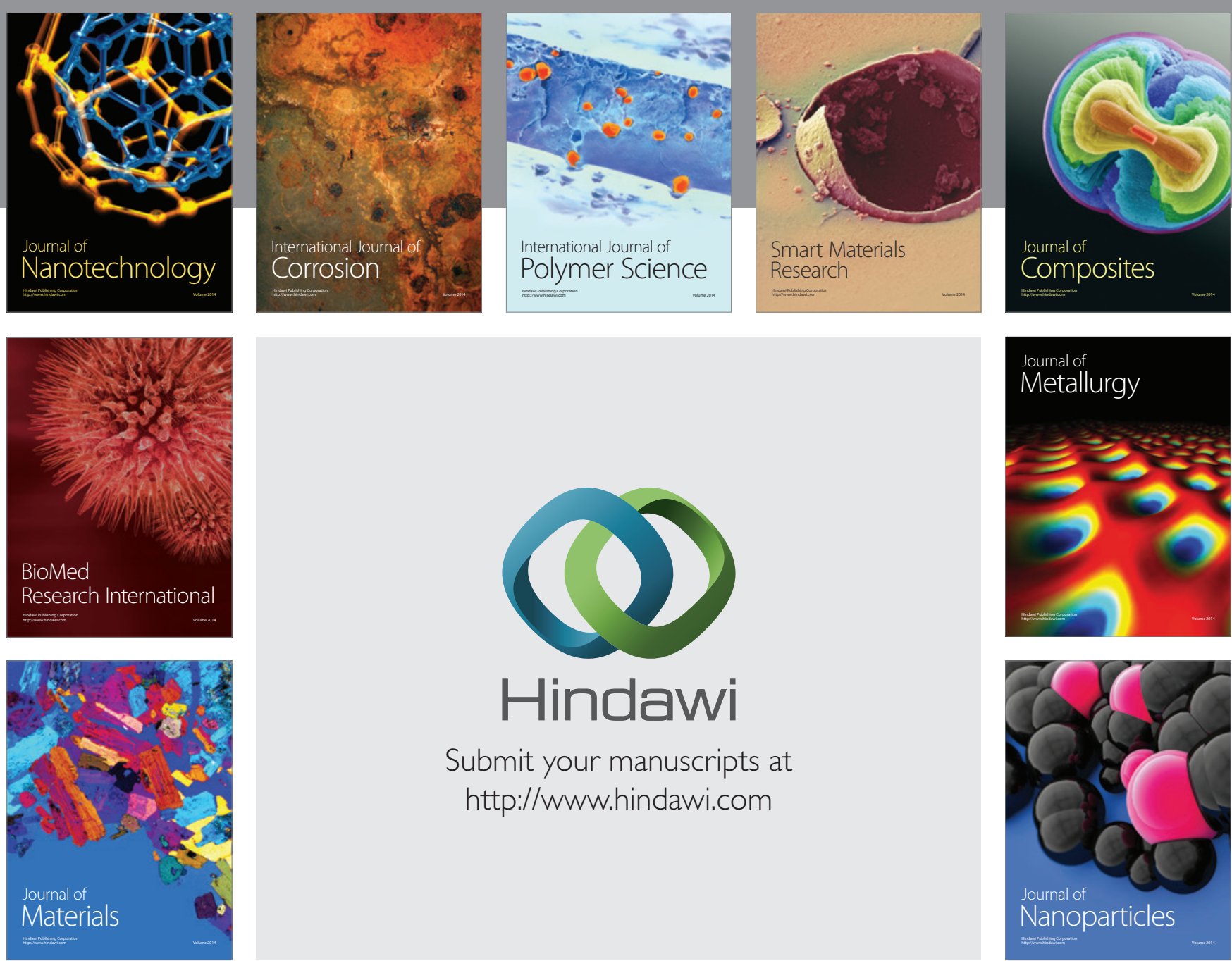

\section{Hindawi}

Submit your manuscripts at

http://www.hindawi.com

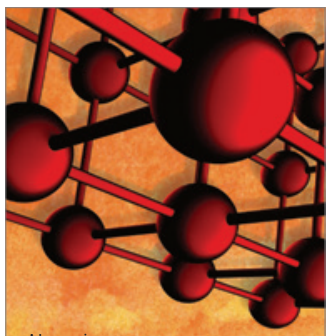

Materials Science and Engineering
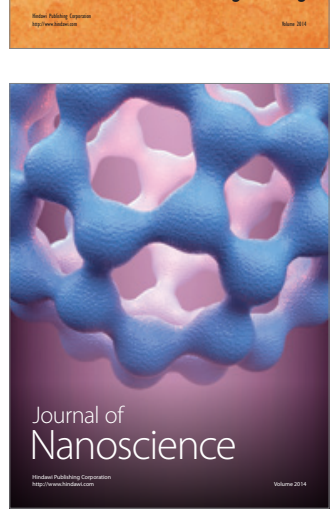
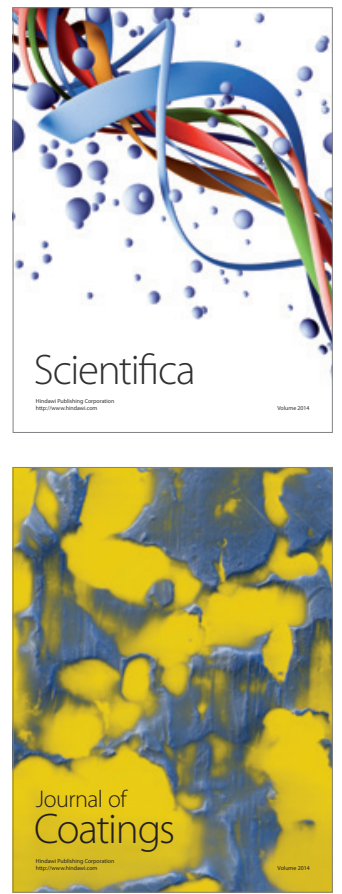
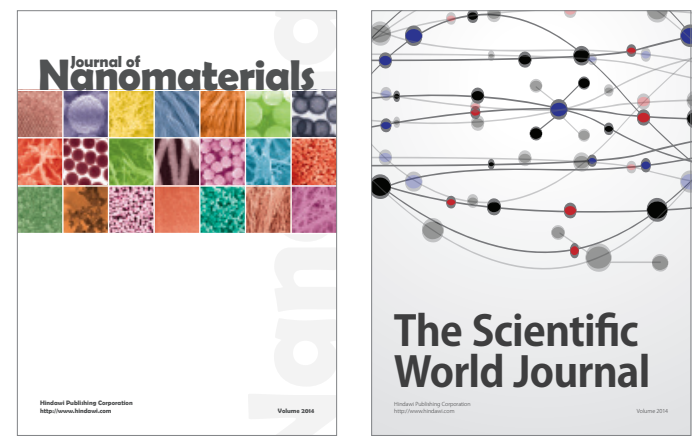

The Scientific World Journal
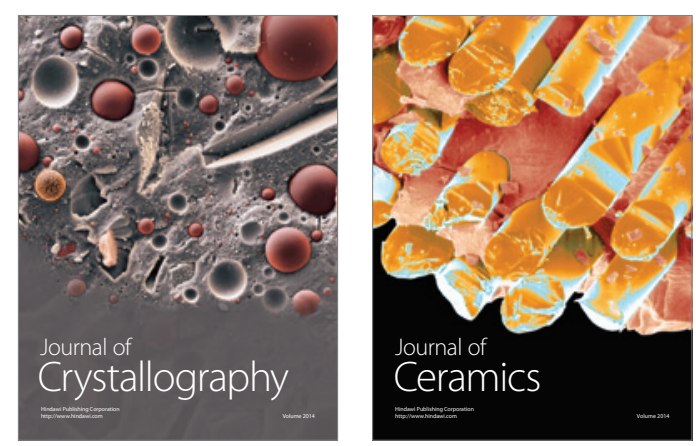
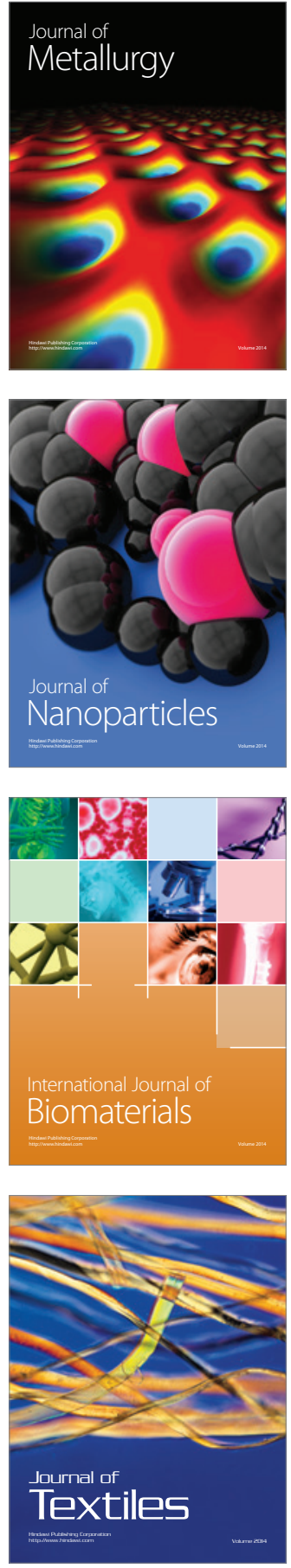